KAIROS ELT JOURNAL, Vol. 2, No. 3, December 2018

Copyright $\bigcirc 2018$, ISSN: 2580-4278

\title{
IMPROVING THE EIGHTH GRADE STUDENTS' READING COMPREHENSIION THROUGH TEAM GAME TOURNAMENT TECHNIQUE AT SMP NEGERI 2 PARAPAT
}

\author{
Vera Nova Sitanggang, Viator Lumban Raja, Jontra J. Pangaribuan \\ Catholic University of Saint Thomas
}

\begin{abstract}
The aim of this study is to find whether Team Game Tournament Technique works effectively on improving students' reading comprehension and to know what the students' responses after being taught by using Team Game Tournament Technique. In order to achieve the objectives of study, a classroom action research was designed and carried out in this study. The participants of this study were 25 students of class VIII-1 of SMP Negeri 2 Parapat in the academic year 2017/2018. Test, observation sheet and field notes were used as the instruments for collecting data. The results of the study showed significant improvement of the students' skill in reading. It is proven by the students' mean score of each test: pre test was 48.80 with $16 \% \%$, formative test was 67,52 with $28 \%$ and post test was 81.52 with $72 \%$. In addition, the analysis result of the observation sheet and field notes showed that Team Game Tournament Technique changed the students' learning behaviour being better than before. They were more enthusiastic during the learnng speaking process in each cycle. Based on the result of those study instruments, it can be concluded that using Team Game Tournament Technique gives the improvement to students' reading comprehension. This technique is seuggested to English teacher to apply it in teaching learning reading in order to improve students' reading comprehension. The writer also suggest to other writers to explore another studies on Team Game Tournament Technique to improve the students' reading comprehension and try to apply this technique in different language skills.
\end{abstract}

Keywords: Reading Comprehension, Reading Comprehension, Classrom Action Research (CAR)

\section{INTRODUCTION}

English is one of languages that is used by people to communicate in the world, and it plays an important role in our life. Through English, we can understand cultures, customs, development of the other countries, and advances of technology in all fields. In relation to the development of English, Indonesian government has organized English to become a compulsory subject in the curriculum of school. It is learned from primary level to university level. In learning English as a foreign language in Indonesia, students have to master the four basic language skills in English. These four basic language skills are categorized as listening, speaking, reading, and writing. They are equally important because those skills are related to each other. One productive language skill is reading. Reading is such an activity in which people get information, knowledge, and ideas from written text. Students should have reading skill because through reading, the students get much information, especially about the educational field.

According to Brassell and Rasinki (2008:15) reading refers to the ability to comprehend or make meaning from a written text. Furthermore, as stated by Mikculecky and Jeffries (1996:1), reading is an important way which can improve the students general language skill in English. It can improve the vocabulary, the writing and the speaking skills, and find out the new ideas, facts and experiences. According to the statement, students can get information and can support other skill in English by applying reading skill. Besides, reading skill is 
KAIROS ELT JOURNAL, Vol. 2, No. 3, December 2018

Copyright $\odot 2018$, ISSN: 2580-4278

required in the final examination. Therefore, the students must have a good readingcomprehension if they want to pass exams and graduate from the school.

Reading comprehension is a multi component, highly complex process that involves many interactions between readers and what they bring to the text (previous knowledge, strategy use) as well as variables related to the text it self (interest in text, understanding of the text types). It is also a process to understanding the meaning of text and to develop skills in finding ideas in text. Kennedy (1981: 192) states that reading comprehension is a through which a reader becomes aware of an idea, understanding in term of their experimental background and interprets it in relation is not a skill or ability that can be develop once and for all at any level of instruction.

From the definition above, the writer concludes that reading comprehension is a process to read a text in order to get information from the text. It means that when we read, we have to understand the information or issue in the text. There are some texts that the students learn in junior high school. They are descriptive text, procedure text, narrative text, analytical exposition text, and hortatory exposition text and etc. Based on the English syllabus of the eighth grade junior high school in first semester, students are expected to able to comprehend narrative text.

Based on the writer's observation in SMP Negeri 2 Parapat in the Academic Year of $2016 / 2017$ when they were learning reading text, it was found that they are unable to comprehend the text well. They tended to focus on the words in the text rather than on the entire text. Therefore, they read slowly word by word and have unreasonable expectations about how much they should be able to comprehend. Besides, they lack of English vocabularies. It makes them rely on their dictionaries in order to find out the meanings of the difficult words. In addition, not all of the students took part actively in learning teaching process. There were many passive students in the class when the teacher was teaching.

To solve the problems above, the teacher should find strategies to improve the students' interest and motivation in reading. English teachers are expected to find an appropriate technique to make students understand the reading text and enjoy reading. Based on the explanation above, this research is focused on finding an alternative technique in teaching reading. It is expected to makes students enjoy in learning and make them confident to show their English ability. And then, the alternative technique is also expected to encourage students' motivation in learning process. The students should feel fun in the classroom during the learning process.

One of the techniques that can be applied to teach this reading is Team Game Tournament. The writer is expected to be able to motivate the students through certain ways. By using Team Game Tournament (TGT), the writer probably can motivate the students to understand reading text. According to Slavin (2005: 64) Team Game Tournament, in which students play academic games with members of other teams contributes points for their team scores. Team Game Tournament is more exciting to the students because this technique looks like playing while learning. The learning does not give burdens to the students, but it is enjoyable to them. The students can work together to get the information from the reading text with various learning styles. Therefore, the teacher hopes that the students will enjoy their learning activity.

In this study, the writer will focus on reading narrative text. The narrative text is one of the genres in reading skill which is must be mastered by students. Anderson and Anderson (1997: 8) state, "Narrative text is a piece of text which tells a story and in doing so entertains and informs the reader or listener". Narratives mostly commence with generic structures, followed by orientation, complication, resolution. According to the statement, students can understand how to understand the text by generic structure. The narrative text is not only a text 
KAIROS ELT JOURNAL, Vol. 2, No. 3, December 2018

Copyright@2018, ISSN: 2580-4278

which is learned at school, but can also be found in our life, such as fairy tales to entertain amuse the readers. That is why learning narrative text in reading skill is very important.

There some previous researches in using team games tournament have been presented to improve reading skill. The first research was conducted by Sari (2012) entitled "Improving Students' Reading Comprehension through Team Game Tournament in Narrative Text at the ninth grade of SMP PAB 10 Medan". It states that the mean score of post-test was higher than the mean score of pre-test. The mean score of pre-test was 65.33 and the mean score of posttest cycle I was 71.72 and cycle II 84.54. The second research was conducted by Agung (2014) entitled "The Effectiveness of using Team Game Tournament in Teaching Reading of Narrative Text at SMP N 1 Paku Haji". It states that the mean score of post-test was higher than the mean score of pre-test. The mean score of pre-test was 58.73 and the mean score of post-test was 70.75. Both of the research findings showed that have shown good result of applying TGT technique. It is suggested that English teacher use make TGT technique as one of alternatives technique in teaching reading.

Based on the explanation above, the writer decides to conduct a reserach entitled Improving Students' Reading Comprehension through Team Games Tournament method to the Second Grade Students of SMP Negeri 2 Parapat.

\section{REVIEW OF LITERATURE \\ 2.1 Reading}

In daily life, reading skills play an important role in facilitating people to comprehend the written materials. They can get a lot of information from various resources in order to enrich their knowledge by reading. Unfortunatelly the people find many problems in reading. According to Nuttal (2000:2) reading means a result of interaction between the writer's mind and the reader's mind. It is the way how to the reader tries to get the message or the intended meaning from the writer. In this process, the reader tries to create the meanings intended by the writer, the reader can get the message, and the writer's meaning sense.

Bernhardt (in Celce-Murcia, 2001: 154) states that reading is an interactive process. In this process, there are some parts that interact each other, namely a text, a reader, and a social context. The reader constructs the meaning in a written text through the symbol that is presented in it. The construction of the meaning is influenced by the reader's experience, language background, cultural framework, and the purpose of reading. Cline et al. (2006: 2) states that reading is the process of deriving meaning from a text. The writer encodes the message in his mind (it can be an idea, a fact, a feeling, an argument, etc.) that he or she wants to share to the readers in the form of written text. Once the text is accessed by the readers, they receive or decode the message from the text.

It can be concluded that reading is important to people's daily life and also reading is not a simple process. It is not only decoding the message from the text but also getting the meaning from the text. It involves an interaction process between the writer and the text and also the transaction between the reader and the writer through the text.

\subsection{Types of Reading}

According to Mickuleckey and Jeffries (1996:14) reading skill can be divided into types they are:

a. Scanning reading

It is making quickly a review of the passage, looking for specific information. Scanning is used to find a particular piece of information. Run your eyes over the text looking for the specific piece of the information you need.

b. Skimming reading

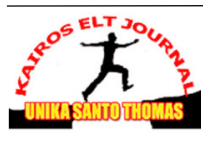


KAIROS ELT JOURNAL, Vol. 2, No. 3, December 2018

Copyright $\odot 2018$, ISSN: 2580-4278

It is getting the general sense of passage or book fast that could save the reader's time. It is sometimes referred to as gist reading. Skimming may help in order to know what the text is about at its most basic level.

c. Intensive reading

It is reading for complete understanding of entire text. Intensive reading is used on shorter text in order to extract specific information. It includes very accurate reading for detail. Intensive reading skills are used to grasp the details of a specific situation. In this case, it is important that you understand the details of the text.

d. Extensive reading

It is rapid reading for main ideas of a large amount of text. Extensive reading is used to obtain a general understanding of a subject and include reading longer.

From those statements, the writer can concluded there are four types in reading that is scanning, skimming, intensive, and extensive. Students are frequently dealing with reading of the types of reading. In reading, students will find new words which they have never heard before. In short, students will find these types reading while they are learning.

\subsection{Reading Comprehension}

According to Klingner, et al. (2007:2) reading comprehension is "the process of constructing meaning by coordinating a number of complex processes that includes word reading, world knowledge, and fluency". It refers to the ability in interpreting the words, to understand the meaning and the relationships between ideas conveyed in a text. Snow (2002:11) states, "Reading comprehension is defined as the process of simultaneously extracting and constructing meaning through interaction and involvement with written language". The process of constructing meaning is the process in which the reader combines their prior knowledge with the additional information from a text, draws the meaning of words, and connect it to reach the clear understanding of the written text.

Alderson (2000: 28) defines reading is an enjoyable, intense, private activity in which the readers get much pleasure and can totally absorb the reading. According to Pang, et al. (2003:14) comprehension is the process of making sense of words, sentences and connected text. He says that comprehension is the processes of deriving the meaning of one word to another in a text. Readers typically make use of background knowledge, vocabulary, grammatical knowledge, experience with a text and other strategies to help them understand written text.

From the definitions above, it can be concluded that reading comprehension is the ability to find the stated or unstated writer's idea in the text. The essence of reading comprehension is understanding all information delivered by the writer. It also refers to the ability to connect between the words in a text, to understand the ideas and the relationships between ideas conveyed in a text.

\subsubsection{Levels of Reading Comprehension}

Burn et al, (1990:177) state that there are four levels of comprehension that must be achieved in reading comprehension. The four levels of reading comprehension are identified as follows:

1. Literal comprehension

The basis of literal comprehension is recognizing main ideas, details, causes and effect, and sequences. It is important since it is as prerequisite for higher-level understanding. It means that the literal comprehension question test the readers' ability to think within the text and consider what has been literally and explicitly stated. There is no hidden meaning so the reader can take what is presented at face level. 
KAIROS ELT JOURNAL, Vol. 2, No. 3, December 2018

Copyright $\odot 2018$, ISSN: 2580-4278

2. Interpretive comprehension

Interpretive comprehension consists of (1) inferring main ideas of passages in which the main ideas are not directly stated; (2) inferring cause-and-effect relationships when they are not directly stated; (3) inferring referents of pronouns; (4) inferring referents of adverbs; (5) inferring omitted words; and (6) drawing conclusion. It means that interpretive meaning often hidden throughout the text and requires the use of inference and understanding the relationship between events and characters or causes and consequences.

3. Critical comprehension

Critical reading is an activity in which the students are able to provide evaluation or take conclusion from a text accurately and compare the ideas in writing. A critical reader must be anactive reader, who always asks, looks at the fact contained in the text to understand the meaning of the text itself.

4. Creative comprehension

Creative reading involves going beyond the material presented by the author. It requires readers to think as they read. It can also help students creatively explore their reading skills in which teacher should be able to be a model in teaching learning process.

Based on the levels of reading above, literal level, inferential level, critical level, and creative level are interconnected. It means, in reading comprehension students must be able master the first level until the fourth level. The level of reading comprehension are the referral in reading that must students comprehend.

\subsubsection{Teaching Reading Comprehension}

Brown (2000: 7) states, "Teaching is an activity in which the teacher guides and facilitates learning, gives a chance for the learners to learn, and sets the condition for learning". Guidance is done by leading the students to do activities in the effort of getting knowledge. The teacher can help the students in gaining the knowledge by giving facilities such as tasks. By giving these tasks, the teacher lets the students study by themselves. To make the teaching and learning process run well, the teacher needs to set a good situation for the students to learn. In setting a good condition, the teacher must consider a classroom method or technique that is used as this can influence the way he or she manages the class.

Based on the definition above, teaching reading comprehension is a guidance that is done by the teacher to make learners reach their reading comprehension on the text using a certain technique. Pang, et al. (2003: 14) state "The teacher can lead the learners to understand a text by using some strategies on reading comprehension". The teacher's responsibilities in helping learners achieve these goals is to motivate the students by selecting or creating appropriate texts, to design useful reading tasks, to set up effective classroom procedures, to encourage critical reading, and to create supportive environment for practicing reading.

\subsubsection{Principles for Teaching Reading Comprehension}

In the teaching of reading, the teacher cannot directly just teach reading to the students by giving texts and asks them to understand it. There are some principles which have to be considered by the teacher. As it is proposed by Harmer (2001: 70-71), there are six principles in teaching reading as described as follows:

a. Reading is not a passive skill. Reading is an incredibly active occupation. To do it successfully, we have to understand what the words mean.

b. interested in what they are doing.

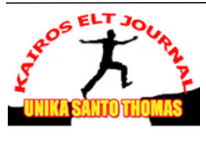


c. Students should be encouraged to respond to the content of a reading text, not just to the language. It is important to study reading texts for the way they use language, the number of paragraphs they contain and how many times they use relative clauses.

d. Prediction is a major factor in reading. When we read texts in our own language, we frequently have a good idea of the content before we actually read.

e. Match the task to the topic. Once a decision has been taken about what reading text the students are going to read, we need to choose good reading task, the right kind of questions, engaging and useful puzzle, etc.

f. Good teachers exploit reading texts to the full. They integrate the reading text into interesting class sequences, using the topic for discussion and further tasks, using the language for study and later activation.

Based on the principles for teaching above the writer concludw that when person is reading piece of writing, his background experience will engage with his language abilities. Through his thinking abilities, he will comprehend according to his purpose on reading. Meanwhile his good teachers exploit reading texts to the full will influence the resut of reading comprehension.

\subsection{Narrative Text}

Narrative text is one of English text types. Narrative text is the text that tells something imaginative or something that is just a fantasy and the goal is only to entertain the reader. Anderson and Anderson (1997: 8) state, "Narrative text is a piece of text which tells a story, entertains, and informs the reader or listener". Meanwhile, Percy (in Permana and Zuhri, 2013:2) states, "Narrative text is a type of text that tells a story or a series of events in which they occur". Its purpose is to give meaning to an event or a series of events by telling story. Ayres (2008:5) states, "Narrative text is one of the forms of developing writing, for example characters told the history of something based on the development of writing from time to time". From the statements above, it is concluded that a narrative text is a text which contains a story ordered chronologically. In order that the text can be enjoyed by the readers, the writer should arrange the text interestingly. The purpose of telling the story is to give meaning, and to entertain the readers.

Narrative text has a core story that is usually only in the form of the author's imagination or a real incident that was captured by the author or even a combination of both. In various sources narrative text can be found in the form of fables (storiesabout animals behave like humans pictured), fairy stories (the story is fantastic, full of wonders), personal experience written, ballads (it is a touching story, usually in the form of a love story), myths (stories that are believed by some people but the stories cannot be true. It was told in an ancient culture to explain a practice, belief, or natural occurrence and legend (it is a simple story which relates to on how a place is formed).

\subsection{Team Game Tournament}

Slavin (2005:166-169) states, "Team Game Tournament technique, which is developed by DeVries and Keith Edwards. TGT is one of the team learning strategies designed for review and mastery learning of material. Organizing the classroom into four or five members for each teams from all achievement. Slavin has found that TGT increased basic skills, students' achievement, positive interactions between students.

It is the same as Students Team Achievement Divisions (STAD), STAD have class presentations, teams, quizzes, individual improvement scores and team recognation. But in TGT, instead of quizzes and individual improvement score systems, TGT uses an academic game tournament. In which students compete as representatives of their teams with members

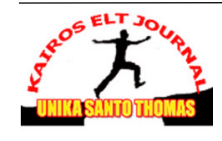


KAIROS ELT JOURNAL, Vol. 2, No. 3, December 2018

Copyright@2018, ISSN: 2580-4278

of other teams who are like them in past academic performance". And STAD based on Slavin (2008:26) "Each students is given a "based" score, derived from the student's average past performance on similar quizzes. Students then earn points for their teams based on the degree to which their quiz scores exceed their base scores". In other words, TGT and STAD have the same several elements but different in using quizzes, STAD uses the common quizzes, while TGT uses classroom.

According to Trianto (2008:83), "TGT can be used for many kinds of subjects, such as: natural science, social science, and also language". It can be inferred that TGT is almost possible used for any kinds of education level, from low until high level education.

\subsubsection{The Principles of Team Game Tournament (TGT)}

According to Slavin (2005:171), TGT has five principles as follows:

a. Class presentation, in TGT is the same as class presentation in Students Teams-Achievement Divisions (STAD), materials are introduced here. Slavin said that this is often the direct instruction or a lecture discussion conducted by the teacher.

b. Teams, teams in TGT is also same as teams in STAD, teams are composed of four or five students who represent a cross-section of the class in terms of academic performance, sex, and race or ethnicity. The major function of the team is to make sure that all team members are learning, and. After the teacher presents the material, the team meets to study worksheets or other material. Most often, the study involves students discussing problems together, comparing answer, and correcting any misconceptions if teammates make mistakes.

c. Game, the game is composed of content-relevant questions designed to test the knowledge students gain from class presentations and team practice. Games are played at tables of three students, each of whom represents of different team. Most games are simply numbered questions on to sheet. A students with a numbered card attempts to answer the question corresponding to the number. A challenge rule permits players to challenge one another ${ }^{\text {re }} \mathrm{s}$ answer.

d. Tournament, the tournament is the structure in which the games take place. It is usually held of the end of a week or a unit, after the teacher has made the class-presentation and the team has had time to practice with their worksheet. Thus, the teams have a good preparation in participation the tournament.

e. Team Score, team scores are computed based on teams ${ }^{\text {ee }}$ members improvement scores, and individual certificated, a class newsletter, or a bulletin broad recognize high-scoring team.

Based on the principles, of TGT, this technique is divided into team, game, tournament, and team score. It will make students enjoy in mastering material in the textbook, as the result they will not feel bored. TGT also makes students participate actively more in the class.

\subsubsection{Teaching Reading through Team Game Tournament (TGT)}

According to Slavin (2000:169) there are several steps to conduct the teaching reading through TGT:

a. Divide the learners into groups of four or five.

b. Give the learners an outline of what they will be learning and why.

c. Present new academic information to learners either verbally, in writing, or through other means such as videotape.

d. Give the learners worksheets or other study devices to help them master the academic materials. These worksheets should guide them through the materials and show them how they can help one an other learn through tutoring, quizzing one another, or team discussing.

e. Give the learners sufficient time to work together to understand the ideas you have presented-several periods if necessary.

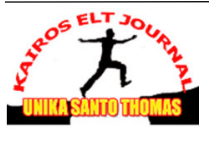


f. While the learners are learning in their groups, review your records of their learning progress over the past few lessons so that you can classify each learner as a low, medium, or high achiever at this time and for their aspect of their learning.

g. When it is time to check on what the learners have learned, select three at a time for the tournament, the three learners should be from some category (low, medium, or high achiever), but from different group.

h. Pose a series of questions (perhaps four) to the "contestant" who will be trying to be the first to answer. At the end of the round the winner earns one points for his/her team regardless of how many questions they answered correctly or how difficult the questions.

From the explanation above, we know that for the first section teachers should present the material, then, divide the students into several groups based on their ability, students can be classified as low students achiever, medium students ${ }^{\text {ee }}$ achiever, and high students ${ }^{\text {ee }}$ achiever. When conducting the tournament, students will compete with the students who have the same level ability. After dividing students into groups, give them several periods to learn together. The last, conducting the tournament and the scoring.

\subsubsection{The Advantages of Applying Team Game Tournament (TGT)}

Slavin (2000:169) describes the advantages of applying TGT in improving reading comprehension. The advantages of this technique include:

1. Students can interact in the small group.

2. Giving the opportunities for the students to solve problems together.

3. Students will have good attitudes because beside they are responsible of their own selves, they also responsible of the team.

4. Increase the students' desire in learning.

5. Motivating the students to compete.

6. Provides the teachers to use new variation in teaching.

7. Provides the teachers to make good assessment.

8. Provides the good atmosphere.

\subsection{Teaching Narrative Text Using Teams Games Tournaments (TGT)}

In teaching narrative text by using Teams Games Tournaments (TGT) teachers should apply some procedures. Firstly, teachers should prepare the learning material and explain it in the class. Secondly, teachers divide the students in to some groups, each group should contain of some level students, high, medium, and low ability. Then, teachers give the opportunity to the groups of the students to study and deal with the learning materials. After discussing, teachers conduct the tournaments, before conducting the tournaments teachers were already prepared the table tournaments and some questions taken from the learning materials.

\section{RESEARCH METHOD}

\subsection{The Research Design}

This research is conducted by applying Classroom Action Research (CAR). Burns (2010:2) says, "Classroom action research is a part of a broad movement that has been going on in education generally for some time. It is related to the ideas of reflective practice and the teacher as researcher". It means that Classroom Action Research is a process of research doing by the teacher for repairing and improving the learning in the classroom. Furthermore, McKay (2006: 29) says, "Action research has three major characteristics: it is carried out by practitioners (i.e., classroom teachers), it is collaborative, and it is aimed at changing things". It means that action research can be done by a teacher in a classroom with the help of other 
KAIROS ELT JOURNAL, Vol. 2, No. 3, December 2018

Copyright@2018, ISSN: 2580-4278

teachers to discuss what and how to improve the classroom activities so that the students' achievement will be better.

Based on the definitions above, the writer can conclude that classroom action research is form of research that applying an idea in a social or educational situation in order to improving or changing something to be better, or to get real effect on the situations. In doing this research, the writer will be helped by a collaborator to help defining and exploring certain problems and needs in the classroom. The writer acts as a real teacher who taught reading to the students by using Team Games Tournament Technique. The collaborator acts as an observer who observed the writer who applies Team Games Tournament Technique in improving students' reading comprehension.

\subsection{Location and Subject of the Research}

The subject of research is the eighth grade students of SMP Negeri 2 Parapat which is located on Jalan Pendidikan No.55 , Parapat Girsang Sipangan Bolon, Simalungun, Sumatera Utara 21741, Indonesia. The writer chooses this school because there has never been any research about improving students' reading skill in narrative text through team games tournament. There are four classes of the eighth grade students. The writer chooses VIII-1 which consists of 40 students, 27 males and 13 females. The reason for choosing the class because the writer finds that the students have some problems in writing, based on preliminary observation.

\section{3 . The Instruments for Collecting Data}

Arikunto (2002: 126) says, "There are many technique that can be used to collect data. They are test, interview, observation, questionnaire, and documentation". In this study, the writer will use field notes, observation sheet, and tests to collect the data.

\subsection{The Procedures of Classroom Action Research}

The writer uses Classroom Action Research (CAR) in conducting the research. The Classroom Action Research (CAR) model used by the writer is developed by Kemmis and Mc. Taggart. This Classroom Action Research (CAR) is arranged into two cycles. They are cycle one and cycle two. Kemmis and McTaggart in Burns (2010: 7) state that action research typically involves four broad phases in a cycle of research. The four phases in a cycle are: (1) planning, (2) action, (3) observation, and (4) reflection.

\section{DATA ANALYSIS AND DISCUSSION 4.1 Data Analysis}

There are two kinds of data, they are qualitative and quantitative methods. The quantitative data were taken from the students' speaking scores while the qualitative data were taken from observation sheet and field notes. Classroom Action Research (CAR) was applied in this study which consisted of two cycles. They are planning, acting, observing, and reflecting. Pre-test was done in the first meeting and formative test at the end of cycle I. The second cycle was also conducted in four meetings including post-test. The quantitative data analysis showed the students' mean score increased continuously. While the qualitative data analysis showed the process of improving students' speaking skill through Patterns of Questions Technique ran well.

\subsection{Discussion}

Patterns of Questions Technique was applied to improve the students' speaking skill of the eighth grade studentss of SMP Dharma Bakti Medan. As the collaborator, the English teacher and the writer collaboratively discussed the result of the study. They concluded that the

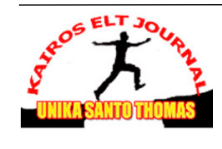


KAIROS ELT JOURNAL, Vol. 2, No. 3, December 2018

Copyright@2018, ISSN: 2580-4278

use of Patterns of Questions Technique could be the effective way to help students in speaking. It was shown in histogram 4.1, in which the mean score of each test improved. The mean score of pre-test was $39,44 \%$, formative test was $56,52 \%$, and the post-test was $69,48 \%$. Those scores showed that the second cycle was better than the first cycle. Besides that, the improvement can be seen from the observation sheet and field notes. Most of the students were more active and enthusiastic during the process of teaching and learning that started from the first to second cycle when the technique was applied.

In conclusion, Patterns of Questions was suitable technique to improve students' speaking skill because this technique gave students a chance to think personally to raise a question with their own language. As the result, the students' speaking score test improved in both of cycle after being taught with Patterns of Questions Technique and also gave good response and condition to all students in teaching learning process.

\section{CONCLUSIONS AND SUGGESTIONS}

\subsection{Conclusion}

After analyzing and discussing the data, the writer draws the following conclusion:

1. The application of Team Game Tournament Technique can improve the students' reading comprehension. It was found out that the students' achievement of reading comprehension on narrtaive texts improved from pre-test to post-test after Team Game Tournament Technique was applied. The increase in the students' total mean score in pre-test is 48.80 , the formative test is 67.25 , and post-test is 81.52 . Meanwhile, the students' score percentage who passed Mastery Minimum Criteria (Kriteria Kelulusan Minimum (KKM)) from pretest is $16 \%$, the formative test is $28 \%$, and the post-test is $72 \%$, the students' score and percentage continuously increased in each test. Therefore, it is concluded that the application of Team Game Tournament Technique can improve the students' reading comprehension on narrative texts successfully.

2. The students' responses were very good. They felt enthusiastic and motivated after being taught with Team Game Tournament Technique. It could be seen from the qualitative data such as observation and field notes during the study.

\subsection{Suggestions}

In this part, the writer would like to give some suggestions as follows:

The English teachers, should be more active and innovative to select the teaching technique to deliver their materials. They could find good technique to get their students' interest in learning English, especially in learning reading comprehension.

1. The students, should pay attention to the rules how to improve their reading comprehension through the application of Team Game Tournament Technique.

2. The other writers, the result of this study is expected to be able to provide valuable information how to improve students' reading comprehension through Team Game Tournament Technique.

3. The readers should, to know the related students' reading comprehension through Team Game Tournament Technique.

4. The other researchers, to explore other studieson Team Game Tournament Technique to improve students' reading comprehension

\section{BIBLIOGRAPHY}

Agung. Sdayu. 2010. The Effectiveness of Using Team Games Tournament in Teaching Reading of Narrative Text at SMP N 1 PakuHaji. Sarjana's Thesis, Faculty of Teachers Training and Education: University of Islamic Syarif Hidayatullah Jakarta.

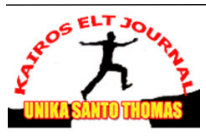


KAIROS ELT JOURNAL, Vol. 2, No. 3, December 2018

Copyright $\odot 2018$, ISSN: 2580-4278

Alderson, Jack. Charles. 2000. Assessing Reading.New York: Cambridge University Press.

Anderson, Mark., \& Anderson, Kathy. 1997. Text Types in English. Sidney: Macmillan Education Australia PTY LTD.

Arikunto, Suharsimi. 2002. Prosedur Penelitian Suatu Pendekatan Praktik (Edisi Revisi V). Jakarta : Rineka Cipta.

2006. Penelitian Tindakan Kelas (Classroom Action Research). Jakarta: Bumi Aksara.

Ayres, Lioness. 2008. Narrative Texts. New York: Plenum Press.

Brassel, Danny., \& Rasinski, Timothy. 2008. Comprehension that Works. Huntington Beach: Shell Education.

Brown, Doughlas. 2000. Principles of Language Learning and Teaching. New York: Longman.

. 2004. Language Assessment: Principles and Classroom Practices. New York: Pearson Education.

Burn, Paul et al. 1990. Teaching Reading in Today's Elementary School. Boston: Houghton Mifflin Company.

Burns, Albert. 2010. Doing Action Research in English Language Teaching: A Guide for Practitioners. New York: Routledge.

Celce-Murcia, Marianne. 2001. Teaching English as a Second and Foreign Language $\left(3^{r d}\right.$ Ed). Boston: Heinle Thpmson Learning Inc.

Cline, Frank et al. 2006. Group Reactions to Three Definitions of Reading. Mineapolis, MN: National accessible.

Harmer, Jeremy. 2001. How to Teach English. Cambridge: Longman.

Klingner, Janet et al. 2007. Teaching Reading Comprehension to Students with Learning Difficulties. New York: The Gulidford Press.

McKay, Sandra. Lee . 2006. Researching Second Language Classrooms. London: Lawrence Erlbaum Associates.

Mickuleckey, Beatiris., \& Jeffries. Linda. 1996. More Reading Power. New York: Addison Wesley Publishing Company.

Nuttal, Christine. 2000. Teaching Reading Skill in Foreign Language. Oxford: Macmillan Heineman.

Pang, Elisabeth. et al 2003. Teaching Reading. Brussel: The International Academy of Education (IAE).

Permana, Tahan. Dwi., \& Zuhri, Faisal. 2013. The Implementation of Picture Series as Media in Teaching Writing of A Narrative Text of the Tenth Graders of Senior High School. Journal of Retain, 1 (1), 1-8.

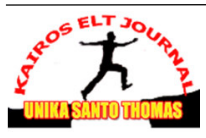


KAIROS ELT JOURNAL, Vol. 2, No. 3, December 2018

Copyright $\odot 2018$, ISSN: 2580-4278

Sari. Desi.Yunanda. 2012. Improving Student's Reading Comprehension through Team Games Tournament at the ninth Grade of SMP PAB 10 Medan. Unpublished Sarjana's Thesis, Faculty of Teachers Training and Education: University of Medan.

Slavin, Robert. Elorida., 2005. Cooperative Learning Theory, Research and Practice. London: Allymand Bacon.

Snow, Catherine . 2002. Reading for Understanding: Toward An R\&D Program in Reading Comprehension. Washington DC: Rand Corporation. 